\title{
Tolmácsolásetika a 21. században
}

\author{
Horváth Ildikó \\ E-mail:horvath.ildiko@btk.elte.hu
}

\begin{abstract}
Kivonat: A tolmácsolásetika kérdése, a tolmács által a tolmácsolt kommunikációs folyamatban betöltött szerep régóta foglalkoztatja a tolmácsolástudományt. A szakmai etikai értékek és elvek, a helyes és helytelen szakmai viselkedés a szakmai etikai kódexekben tükröződik. A tolmácsokat és fordítókat tömörítő országos és nemzetközi szakmai szervezetek többsége kidolgozta az etikai kódexét, ezekböl kirajzolódik néhány univerzálisnak tekinthető elv, úgymint a titoktartás, a pártatlanság, a szakmai felkészültség. Az új technológiák, a mesterséges intelligencia, és legújabban a 2020-as egészségügyi világválság által előidézett helyzet alapjában megváltoztatta a tolmácsok munkakörülményeit, a munkavégzés módját. Ez a változás a tolmácsolás terén olyan kérdéseket vet fel, amelyek közvetlenül érintik a tolmácsolásetika egyetemes alapelveit is.
\end{abstract}

Kulcsszavak: tolmácsolásetika, etikai kódexek, etikai alapelvek, új technológiák, mesterséges intelligencia

\section{Bevezetés}

Az etika vagy morálfilozófia az a tudományterület, amely az erkölcsileg jó és rossz, helyes és helytelen meghatározásával foglalkozik. Ez a gyakorlati filozófia azon ága, amely az egyes társadalmak vagy társadalmi csoportok által lefektetett erkölcsi értékek elméletét és rendszerét tanulmányozza, és ily módon az egyének viselkedését, tetteit, valamint jogait és kötelezettségeit vizsgálja. A szakmai etikai értékek, viselkedési normák jellemzően a szakmai etikai kódexekben jelennek meg. A tolmácsolástudomány már régóta foglalkozik a tolmácsolásetikai kérdések és az etikai kódexekben tükröződő szakmai elvek, viselkedési „elöírások” problematikájával. A tolmácsolásetikai kódexekkel kapcsolatos kutatásokra vonatkozóan elmondható, hogy azokat szemtől szembeni, azon belül is elsősorban a közösségi tolmácsolási helyzetekben igen mélyrehatóan tárgyalták már (Phelan et al. 2020).

Hivatkozás: Horváth I. 2021. Tolmácsolásetika a 21. században. Fordítástudomány 23. évf. 1. szám. 5-20. DOI: https://doi.org/10.35924/fordtud.23.1.1 
Ennél sokkal kevesebb tudományos jellegü kutatás készült a konferenciatolmácsolás területén (Horváth és Tryuk 2021).

A szóbeli szinkrontolmácsolás esetében ehelyett a tolmácsolástudományt inkább olyan kérdések foglalkoztatták, mint a forrásnyelvi üzenetnek a célnyelvre való közel egyidejü átültetése, tehát a szinkronitás által támasztott kognitív komplexitás, az ezzel járó emlékezeti kapacitás és információfeldolgozásbeli sajátosságok, figyelemmegosztás, szegmentáció, stresszkezelés, vagy a többcsatornás nyelvi és nem nyelvi információfeldolgozás körülményeinek a tolmács teljesítményére gyakorolt hatása.

Mindazonáltal a konferenciatolmácsolásnak a 20. század elején való megjelenése és a II. világháborút követő elterjedése meghatározó hatással bírt a tolmácsok által betöltött szerepek és feladatok tekintetében. Ezeket a különböző tolmácsolási területekre vonatkozó tolmácsolási etikai kódexek is jól tükrözik (pl. AUSIT, Chartered Linguists, CHIA, EULITA, NAD-RID, NAJIT, EULITA). Pöchhacker és Shlesinger alapján elmondható, hogy ezt megelőzően a tolmácsok egyfajta mindenes közvetítők voltak, akik a tolmácsolás feladata mellett mindenféle egyéb funkciót, például szervezői vagy adminisztratív feladatokat is elláttak. A konferenciatolmácsolás térnyerésével és elfogadottá válásával azonban élesebben elkülönült, hogy mi várható el a tolmácsoktól magas szintü, nagy nyilvánosságnak örvendő nemzetközi találkozók során és mi nem. A konferenciatolmácsok szinkrontolmácsolást végeztek tolmácskabinból, tehát fizikailag is egyértelmüen elkülönültek a tolmácsolási események résztvevőitől, valamint nagy presztízsnek örvendtek. Mindez feltehetően hozzájárult ahhoz, hogy a szerepük immár a kommunikációs folyamatban jobban körülhatárolhatóvá vált, hiszen a többi résztvevővel való közvetlen érintkezés lehetösége is csökkent, s elsősorban az üzenet célnyelven való megfogalmazásában merült ki (Pöchhacker és Shlesinger 2002). A konferenciatolmácsolás professzionalizálódása elősegítette, hogy általában a tolmácsok által betöltött szerepeket és feladatokat egyértelműbben meg lehessen határozni, és az általuk elvárt feladat magára a tolmácsolásra, azaz a többnyelvü kommunikáció elősegítésére korlátozódjon.

Ezzel együtt elmondható, hogy a tolmács szerepének kutatása a tolmácsolástudományban elsősorban a közösségi és hatósági tolmácsoláskutatás megerősödésével nyert teret. Ezekben a tolmácsolási helyzetekben elsősorban rövid szakaszos, összekötő tolmácsolási módot alkalmaznak, és a tolmácsolási helyzetet a kommunikációs folyamat résztvevői közötti intenzív interakció jellemzi. A kutatókat elsősorban a tolmácsnak a kommunikációs folyamat többi szereplöjével való interakció során betöltött szerepe érdekelte (Hale 2004, Kalina 2015, Mikkelson 2000, Roy 2002, Wadensjö 1998) és elindultak a különböző tolmácsolási helyzetekre (bírósági, egészségügyi, bevándorlási, stb.) jellemző tolmácsolásetikai kérdésekre vonatkozó kutatások (Angelelli 2003, Bot 2003, Gentile et al. 1996, Phelan et al. 2020, Schweda Nicholson 1994). A tolmácsolástudományban az az érdekes helyzet állt elö, hogy annak ellenére, hogy a konferenciatolmácsolás katalizátorként müködött a tolmács szerepének meghatározásában és a tolmácsolás professzionalizá- 
lódásnak folyamatában, valamint, hogy az első tolmácsolási etikai kódexet a Konferenciatolmácsok Nemzetközi Szervezete (AIIC) alkotta meg 1957-ben, a tolmácsolásetikára a tudományos közösség figyelmét a nem konferenciatolmácsolást kutatók hívták fel.

A továbbiakban a tolmácsolásetikai kódexekben lefektetett, a tolmácsok szakmai viselkedését alapvetően meghatározó etikai elvek bemutatása következik. Szó esik általában az etikai kódexek szerepéröl, s azok preskriptív jellegét érő kritikákról. Ezt követően a tolmácsolás területén az új technológiák igen gyors és nagymértékü térnyerése által okozott új szakmai etikai kihívásokról lesz szó.

\section{Tolmácsolásetikai kódexek}

Az etikai kódexek a szakmai sztenderdeket határozzák meg, leírják az adott szakmára vonatkozó alapvető elveket és normákat, azaz a szakmai viselkedést meghatározó elvekre vonatkozó ismeretek forrásai. A tolmácsolás tekintetében Kermit (2007) kijelenti, hogy az etikai kódexeknek az a szerepe, hogy meghatározzák, hogy a jó tolmácsok hogyan járjanak el. A ,jó" fogalmát két értelemben lehet értelmezni ebben a kontextusban. A ,jó” jelző egyrészt a tolmács gyakorlati hasznára, másrészt az erkölcsi értelemben vett kvalitására vonatkozik. A tolmácsok számára kidolgozott etikai kódexek leírják a tolmácsok „,modus operandiját”, azaz munkamódszerét, eljárási módját. Edwards (1995) kiemeli, hogy a bírósági tolmácsolási etikai kódexek útmutatást nyújtanak a tolmácsnak a tárgyalótermi viselkedéshez. Megemlíti továbbá, hogy mivel a tárgyalóteremben gyakran a tolmács az egyetlen, aki a tolmácsolt bírósági tárgyalás mindkét nyelvét ismeri, igen nagy befolyással rendelkezik. Az etikai kódexnek az a funkciója, hogy a tolmács számára iránymutatást nyújtson arra vonatkozóan, hogyan használja felelősségteljesen ezt a hatalmat.

Az etikai kódexek egy másik funkciója az adott szakmára vonatkozó ismeretek, tudás és tapasztalat megosztását segíti elő. Ezáltal a szakmává válás folyamatában, a szakma megerösödésében is jelentős szerepet játszanak azáltal, hogy a legfontosabb irányelveket lefektetik. Ez azt is jelenti, hogy nagymértékben hozzájárulnak a szakmatudat kialakulásához és megerösödéséhez. A szakmatudat azt jelenti, hogy a szakember, így a tolmács is, tisztában van azzal, hogy az általa végzett tevékenység miben különbözik a többitől, mi a különbség például a tolmács, a fordító és a nyelvtanár tudása, készségei, kompetenciái, feladatai között. Mindezt egyszerúen és világosan, de a szakma metanyelvén szakszerüen el is tudja magyarázni a kívülállók számára is. A szakmatudattal rendelkező tolmács továbbá tisztában van a hivatásos szakmai viselkedés ismérveivel is.

A hivatásos viselkedést nagyban meghatározza a hivatásos attitüd. Az etikai kódexek ennek kialakításában is segítséget nyújtanak a tolmácsok számára. Snyder (1994) a fordítók számára 12 szempontot javasolt a professzionalizmus javítása érdekében, amelyek a tolmácsoknak is hasznos lehetnek. Ezek a tanácsok az er- 
kölcsileg helyes szakmai viselkedés gyakorlati oldalát mutatják be: önismeret, szakmai ismeretek, becsületesség, pontosság, precizitás, munkavégzéshez külön telefonvonal, öltözködés, barátságosság, személyeskedés kerülése, vállalt feladat elvégzése, a megbízónak-mindig-igaza-van elv, türelem, szerénység (bővebben lásd Snyder 1994: 16-21). Ezek az elvek jó kifejezik a szakember azon törekvését, hogy a tőle telhető legjobbat nyújtsa olyan szakmai etikai elvek alapján, mint a pontos munkavégzés, diszkréció és semlegesség, saját magunk és szakmai környezetünk tiszteletben tartása, valamint a szakmai alázat.

\subsection{Az etikai kódexek preskriptív jellege}

El lehet mondani, hogy a tolmácsolási etikai kódexek alapvetően preskriptív jellegüek, azt írják elő, hogy a tolmácsnak hogyan kell cselekednie. Általában véve elmondható, hogy kinyilvánítják: a tolmácsnak visszahúzódónak, lehetőség szerint láthatatlannak és pártatlannak kell lennie, és a szerepük kimerül a tolmácsolásban (Fowler et al. 2013). Az ilyen jellegü kódexek a láthatatlan tolmács fekete doboz mítoszát, esetleg az ideális tolmács mítoszát örökítik meg. Roy (2002) szerint a bírósági tolmácstól azt várják el, hogy az üzenetet pontosan, precízen, érzelmi és személyes szubjektivitástól mentesen, a beszélöi szándék megváltoztatása nélkül reprodukálja a célnyelven. Mindezt a lehető legpontosabban, elfogultságmentesen és semleges hozzáállással. Ez azt jelenti, hogy a tolmács nem hozhat fel semmilyen témát, nem kérdezhet vissza, nem fejezhet ki véleményt és nem adhat tanácsot, és mindezt a titoktartás szigorú elvének betartásával. A tolmácsot ebben a szerepben gyakran géphez, szócsőhőz, ablakhoz, hídhoz vagy telefonhoz hasonlították, ami a tolmács komplex szerepét annak csupán egy aspektusára szükíti le (Roy 2002). Ez a szerep a tolmácsolástudományban az ún. csatorna modell (conduit modell) tolmácsszerepének felel meg.

A tolmácsnak a kommunikációs helyzettől való elidegenítését a konferenciatolmácsolási helyzet megjelenése és elterjedése is felerősítette, ugyanis a tolmácskabin jól lehatárolta a tolmácsolt kommunikációs helyzetben a tolmács által betöltött fizikai, társadalmi és kommunikációs szerepet. A tolmácsra egyfajta automataként tekintettek, aki beszédeket reprodukál, és a munkája mögött ritkán jelenik meg az ember. A 2000-es évek elejére azonban a tolmács megítélésében változás következett be. Ekkor a tolmácsolástudományban megjelent egy új megközelítés, amely mentén a tolmács láthatóságát/láthatatlanságát vizsgálták a különböző tolmácsolási helyzetekben és módokban, pl. a közösségi, bírósági, konferencia és jelnyelvi tolmácsolás (Angelelli 2003, Bischoff et al. 2012, Bot 2003, Diriker 2004, Tate és Turner 2002, Horváth 2015, Lee 2009, Monacelli 2009, Roy 2002, Wadensjö 1998). Manapság a tolmácsnak ez a kodifikált viselkedése már meghaladottá vált, inkább számít egyfajta mítosznak, mint valóságosnak (Fowler at al. 2013, Katan és Straniero-Sergio 2001, Monacelli és Punzo 2001). A tolmácsra egyre inkább emberi lényként, mintsem személyiséggel nem rendelkező láthatatlan eszközként tekintünk. 
Miután mára már a csatorna modell, a tolmács mint láthatatlan szócső elmélete megdőlt, a tolmácsolásra szituációba ágyazott tevékenységként tekintünk, ami azt is jelenti, hogy a tolmácsok folyamatosan változó környezetben végzik a tevékenységüket. Ennek megfelelően, ahogy Monacelli és Punzo (2001) rámutat, a szakmai etikának nem a tolmács elvont értelemben vett viselkedésére kell vonatkoznia, hanem arra, egy adott helyzetben milyen elvek alapján válasszon a szabályok között és azokat hogyan alkalmazza.

A tolmácsolást kutatók többnyire egyetértenek abban, hogy az etikai kódexek nem tükrözik a tolmács új láthatóságát, jóllehet léteznek olyan tolmácsolásetikai kódexek, amelyek példával illusztrálják a tolmács etikus viselkedését (lásd pl. a CHIA, a NAD-RID vagy az AUSIT etikai kódexeit). Schweda Nicholson (1994) például megállapítja, hogy a legtöbb tolmácsolásetikai kódex általában nem nyújt konkrét példákat arra, hogy a különösen nehéz és nagy kihívást jelentő bírósági vagy közösségi tolmácsolási helyzetekben hogyan érdemes cselekedni. Mikkelson (2013) azokat a kutatási eredményeket vizsgálta, amelyek arra vonatoznak, hogy a tolmácsok maguk hogyan látják a szerepüket, és arra a megállapításra jutott, hogy a tolmácsok között sincs egyetértés a tolmácsolási folyamatban betöltött szerepük tekintetében. Voltak, akik hangsúlyozták a felhasználók által támasztott elvárások és a tolmácsok saját nézetei közötti különbséget azzal kapcsolatban, hogy a tolmácsnak hogyan kellene és hogyan nem kellene viselkednie, valamint aközött, amit a tolmácsképzésben tanultak erről, és ahogy valójában tolmácsként cselekednek. Ez a kutatás továbbá felhívja a figyelmet arra, hogy a tolmácsok gyakran éreznek lelkiismeretfurdalást amiatt, valamint stresszforrás is számukra az, ha úgy érzik, helytelenül cselekedtek, illetve ha megbízói nyomásra kénytelenek megszegni a tolmácsolásetikai szabályokat. Setton és Prunč (2015) ezenfelül megjegyzi, vannak olyan összetett helyzetek, mint például a konfliktuszónákban való tolmácsolás, amelyekben a tolmácsoknak kifejezetten nehéz megfelelni a tolmácsetikai elvárásoknak.

Elmondható tehát, hogy igen nehéz a tolmácsolásetikai kódexekben megfogalmazott alapelveket minden körülmények között betartani. Mindez elsősorban azért van így, mivel a tolmácsolás nem egyfajta kontextustól megfosztott ürben megy végbe, hanem az egy szituációba ágyazott többnyelvü szóbeli nyelvi és kulturális közvetítés. A tolmácsolt kommunikációs folyamat során a kontextus, a résztvevők szándéka és nézőpontja folyamatosan változik. A kommunikáció során a tolmácsnak nyelvi és nem nyelvi döntéseket szükséges hoznia annak érdekében, hogy a folyamatot elösegítse és támogassa, hiszen végső soron ez a legfontosabb feladata és szerepe. Óhatatlanul lehetnek olyan szereplői a kommunikációs folyamatnak, akik ezeket a döntéseket nem feltétlenül támogatják.

A tolmácsolásetikai kódexek mindazonáltal hasznos eszközöknek bizonyulnak, amennyiben meghatározzák a hivatásos viselkedést, $\mathrm{s}$ a tolmácsoknak e tekintetben iránymutatást nyújtanak. A helyes alkalmazásuk érdekében azonban hivatásos attitűd és a szakmai „fogások” ismerete szükséges, hogy szakmai etikai dilemmák esetében helyes döntések szülessenek. Kermit (2007) szerint annak 
eldöntésében, hogy egy adott helyzetben mi a helyes eljárásmód a tolmács részéröl, a „bölcsesség” jobb tanácsadó, mint a szabályokban és kódexekben foglalt elöírások.

\subsection{Az etikai kódexek gyakorlati haszna}

A tolmácsolási kódexek gyakorlati hasznának megértése érdekében több szempontot is figyelembe kell venni. Elöször is, mint ahogy már fentebb láttuk, ezek kétségtelenül hozzájárulnak egy tevékenység professzionalizálódásához. Wilensky már 1964-ben megfogalmazta, az etikai kódex elfogadása a professzionalizálódási folyamat ötödik és egyben végső állomása (a teljes állásban végzett tevékenység, a képzés, a szakmai szervezetek megalakítása, a jogi védelem kialakítása után) (Wilensky 1964 idézi Grbič 2015).

Másodsorban, a tolmácsolási etikai kódexek a tolmácsok számára szakmai identitást, integritást és autonómiát is biztosítanak. Ezeket saját maguknak és szakmai partnereiknek (megbízók, felhasználók, eseményszervezők, kollégák) egyaránt tiszteletben szükséges tartani. Katan és Straniero-Sergio (2001) álláspontja szerint mint minden szakembert, a tolmácsokat is megilleti az, hogy szaktudásukat és korlátaikat egyaránt tiszteletben tartsák.

Harmadsorban, mivel az etikai kódexek a hivatásos viselkedés szabályait fektetik le, a szakma iránt viselt felelősség érzését is kialakítják. Útmutatót nyújtanak azokban az esetekben, amikor a szakember valamilyen etikai dilemmával találja szembe magát. Tate és Turner (2002) szerint a tolmácsok ilyenkor a problémát felmérik és spontán stratégiákat alkalmaznak azok megoldására az etikai kódex általuk értelmezett szellemiségének alapján. Végezetül pedig a szakmai etikai kódexek nemcsak tolmácsok és a tolmácsszakma számára hasznosak, hanem a szakmán kívülieknek is segítséget nyújtanak arra vonatkozólag, hogy mit várhatnak el a tolmácstól és mit nem.

Ahhoz, hogy a tolmácsolási etikai kódexek létjogosultságát megértsük, érdemes az azokkal szemben támasztott elvárásainkat átgondolni, és elfogadni azt, hogy egyetemes, minden tolmácsolási módra és helyzetre alkalmazható, a tolmács viselkedését univerzálisan szabályozó tolmácsolásetikai kódex nem létezhet. Az etikai kódexekben foglaltakat nem is annyira szabályoknak és elöírásoknak, hanem inkább olyan paramétereknek kellene értelmezni, amelyek között a tolmácsolásszakmai döntéseket meghozzuk, hiszen egy szakma etikai kódexétől sem várható el, hogy egyértelmüen kimondja, mikor hogyan kell eljárni.

A szakmai etikai kódexek funkciója hasonló a közlekedési szabályokéhoz, hiszen autóvezetés közben is elképzelhető olyan helyzet, amikor a szabályok megszegésével tudunk megelőzni egy balesetet. Például egy frontális ütközést akadályozhatunk meg azzal, ha a mi sávunkban szembejövő autó elől akár a záróvonalat megsértve áthajtunk az üres, szembejövő forgalmi sávba. Ezáltal megszegjük ugyan azt az általános közlekedési szabályt, hogy a záróvonalat tilos átlépni, de lehet, hogy egy súlyos közlekedése balesetet előzünk meg. 
A tolmácsolás annak ellenére, hogy igen heterogén tevékenység (jogi, közösségi, összekötö, egészségügyi, konferencia, háborús konfliktuszónákban végzett, stb.), a tolmácsok szakmai közösséget alkotnak, amelyre alapvetö közös szakmai etikai elvárások vonatkoznak. Ha megnézzük a főbb nemzetközi szakmai szervezetek etikai kódexeit, érdekes megfigyelni, hogy a különbözö tolmácsolási fajták között átfedés van az alapvető szakmai etikai elveket illetően, ami egyfajta konszenzusra utal a tolmácsszakmán belül (lásd 1. táblázat a 3. fejezetben). Minden tolmácsolási eseményre egy adott kontextusban kerül ugyan sor, azonban ezzel egy időben az is igaz, hogy léteznek olyan alapvető kritériumok, amelyek a tolmácsolási tevékenység mint nyelvi szolgáltatás természetéből fakadnak, amely során az ügyfél számára nyújtott szolgáltatáskor az ügyfél érdekeit is szükséges figyelembe venni. Az a tény pedig, hogy az etikai kódexek témája a tolmácsolástudományban visszatérö kutatási terület, jól mutatja a szakmai etikai összetettségét. Ezenfelül, ahogy Van Wyke (2013) megjegyzi, a nyelvi és kulturális közvetítőként elfoglalt helyünk és szerepünk folyamatos vizsgálata már önmagában egyfajta morális cselekedet.

\section{A föbb tolmácsolásetikai elvek}

A tolmácsolástudományban már több szerző is áttekintette a tolmácsolásetikai kódexekben visszatérő alapelveket. Kermit (2007) például három fö etikai elvet azonosított az általa vizsgált dokumentumokban. Ezek (1) a diszkréció és titoktartás, (2) a semlegesség és a tolmácsoláson kívüli feladatok elvégzésének visszautasítása, valamint (3) az elhangzottak teljes és pontos átadása a célnyelven.

Schweda Nicholson (1994) a bírósági és közösségi tolmácsolásra vonatkozó etikai kódexekben hét általánosan előforduló témakört talált: (1) a tolmács szerepe, (2) kompetencia és készségek, (3) elfogulatlanság, (4) teljesség és pontosság, (5) érdekellentét és a kizárás indokai, (6) titoktartás, (7) szakmai továbbképzés.

Bírósági tolmácsolásra vonatkozó müvében Edwards (1995) a tolmácsetikára vonatkozó részben a következő témákat fejti ki: titoktartás, elfogulatlanság, a véleménynyilvánítás tilalma, az ügybe való be nem avatkozás elve, valamint az elkövetett hiba beismerésére való hajlandóság. Gentile et al. (1996) szerint a tolmácsolásra vonatkozó szakmai etikai kódexekben a leggyakrabban előforduló alapvető elvek a titoktartás, az elfogulatlanság és az érdekütközés kerülése. Horváth (2013) öt bírósági tolmácsolásra vonatkozó etikai kódexet vizsgált, és a következő visszatérő elvekre mutatott rá: (1) semlegesség, (2) titoktartás, (3) hivatásos viselkedés és (4) nyelvi pontosság.

Bancroft (2005) összesen 145 dokumentumot nézett át 11 nyelven 25 különböző országra vonatkozóan. Ez a tolmácsolásetikai kódexek tekintetében eddig elvégzett legszélesebb körü felmérés, melynek eredményeképpen öt olyan alapelvet talált, amely gyakorlatilag mindegyik kódexben megtalálható. Ezek (1) kompetencia, (2) integritás, (3) titoktartás, (4) semlegesség, és (5) az eredeti beszéd hü tolmácsolása. 
Phelan et al. (2020) a konferenciatolmácsolás és a hatósági tolmácsolás terén végzett kutatása eredményeképpen megjegyzi, hogy etikai és szakmai gyakorlatra vonatkozó dokumentumokban számos olyan szempont is megtalálható, amelyek első látásra nem etikai kódexbe valók. Ilyenek például az adózás, a díjazás kérdése, az ajándékok elfogadása, a vesztegetés és korrupció, az ügyfelek „elhalászása” korábbi megbízóktól, a tolmács szabály- vagy törvénysértő magatartása, megbízások kiszervezése, az események nyilvános kommentálása, valamint szankciók és fegyelmi eljárások. Ezek helyi jellegzetességeket mutatnak, és azt jelzik, hogy az országos szakmai szervezethez beérkezett panaszok és a médiában tárgyalt ügyek révén gyakrabban jut a tudomásukra helytelen etikai viselkedés a tolmácsok részéröl.

Magyarországon két országos szervezet tömörít fordítókat és tolmácsokat: az 1989-ben alapított Magyar Fordítók és Tolmácsok Egyesülete (MFTE), és a 2016ban létrejött Szoft, a szabadúszó fordítókat és tolmácsokat tömörítő egyesület. Ezek közül az MFTE rendelkezik etikai kódexszel, amelynek a legfrissebb verziója 2015-ben készült el, és az alábbi témákra tér ki: törvénytisztelet, szakmaiság, önképzés, felelősség, empátia, pártatlanság, titoktartás, tisztesség, verseny és tisztességes piaci magatartás, szolidaritás, hírnév, vitarendezés, etikai bizottság, valamint az etikai elvek frissítése a piaci környezet változása esetén.

Az alábbiakban nagyon röviden egy olyan összehasonlítás következik, amelyben nagyobb országos és nemzetközi etikai kódexek által felsorolt elvek szerepelnek. A legtöbb országos és nemzetközi szervezet kidolgozta a saját etikai kódexét. A jelen elemzés az alábbiakra tér ki:

- Standards for Healthcare Interpreters, Ethical Principles, Protocols and Guidance on Roles and Intervention, California Healthcare Interpreting Association's Standards (CHIA);

- Code of Professional Conduct, the US Registry of Interpreters for the Deaf (NAD-RID);

- Code of Professional Conduct, Chartered Institute of Linguists (CIOL);

- Code of Ethics, Australian Institute of Interpreters and Translators (AUSIT);

- Code of Ethics and Professional Responsibilities, National Association of Judiciary Interpreters and Translators (NAJIT);

- Code of Professional Ethics, European Legal Interpreters and Translators Association (EULITA);

- Code of Professional Ethics, International Association of Conference Interpreters (AIIC),

- Etikai Kódex, Magyar Fordítók és Tolmácsok Egyesülete (MFTE).

A fenti dokumentumok kiválasztását három fő szempont vezérelte: (1) különböző tolmácsolási területek bemutatása (egészségügyi, jogi, konferencia, jelnyelvtolmácsolás), (2) országos és nemzetközi jellegü etikai kódexek is szerepeljenek az elem- 
zésben, valamint (3) olyan dokumentumok kiválasztása, amelyek tolmácsolásetikai referenciává váltak. Az elemzés során a dokumentumokban szereplő kulcsfogalmakra összpontosítottunk, az elemzéshez a kulcsszótechnikát alkalmaztuk. A vizsgált etikai kódexekben pl. a titoktartás (secrecy) vagy az információk bizalmas kezelése (confidentiality) illetve a pártatlanság (impartiality) vagy a semlegesség (neutrality) kifejezések váltakoznak. Az 1. táblázatban az elvek lényegét próbáltuk megragadni, és nem az azokat jelölö kifejezésekre összpontosítottunk. Az is elöfordul, hogy egy elv csak indirekt módon szerepel valamelyik kódexben (pl. a munkakörülmények), ilyen esetben is bevettük azokat az elemzésünkbe, amenynyiben az adott etikai kódex szellemiségét tükrözik.

1. táblázat

A föbb tolmácsolásetikai alapelvek

\begin{tabular}{|c|c|c|c|c|c|c|c|c|c|}
\hline & & 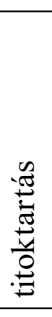 & 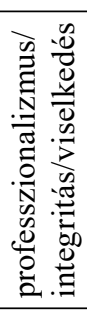 & 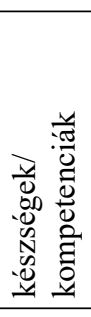 & 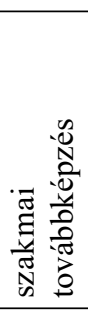 & 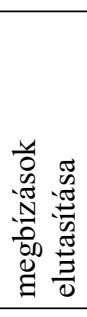 & 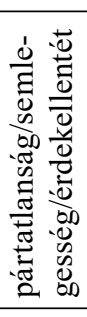 & 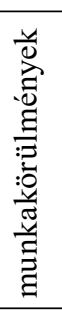 & 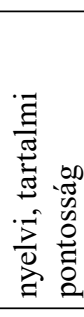 \\
\hline CHIA & $\begin{array}{l}\text { egészségügyi } \\
\text { tolmácsolás }\end{array}$ & $\sqrt{ }$ & $\sqrt{ }$ & $\sqrt{ }$ & $\sqrt{ }$ & $\sqrt{ }$ & $\sqrt{ }$ & $x$ & $\sqrt{ }$ \\
\hline NAD-RID & jelnyelvtolmácsolás & $\sqrt{ }$ & $\sqrt{ }$ & $\sqrt{ }$ & $\sqrt{ }$ & $\sqrt{ }$ & $\sqrt{ }$ & $\sqrt{ }$ & $\sqrt{ }$ \\
\hline AUSIT & általános (fordítók is) & $\sqrt{ }$ & $\sqrt{ }$ & $\sqrt{ }$ & $\sqrt{ }$ & $\sqrt{ }$ & $\sqrt{ }$ & $\sqrt{ }$ & $\sqrt{ }$ \\
\hline NAJIT & bírósági (fordítók is) & $\sqrt{ }$ & $\sqrt{ }$ & $\sqrt{ }$ & $\sqrt{ }$ & $\sqrt{ }$ & $\sqrt{ }$ & $\sqrt{ }$ & $\sqrt{ }$ \\
\hline CIOL & nyelvi szolgáltatás & $\sqrt{ }$ & $\sqrt{ }$ & $\sqrt{ }$ & $\sqrt{ }$ & $\sqrt{ }$ & $\sqrt{ }$ & $x$ & $x$ \\
\hline EULITA & jogi (fordítók is) & $\sqrt{ }$ & $\sqrt{ }$ & $\sqrt{ }$ & $\sqrt{ }$ & $\sqrt{ }$ & $\sqrt{ }$ & $\sqrt{ }$ & $\sqrt{ }$ \\
\hline AIIC & konferenciatolmácsolás & $\sqrt{ }$ & $\sqrt{ }$ & $\sqrt{ }$ & $\sqrt{ }$ & $\sqrt{ }$ & $x$ & $\sqrt{ }$ & $x$ \\
\hline MFTE & általános (fordítók is) & $\sqrt{ }$ & $\sqrt{ }$ & $\sqrt{ }$ & $\sqrt{ }$ & $\sqrt{ }$ & $\sqrt{ }$ & $\times$ & $x$ \\
\hline
\end{tabular}

Az eddigiek összegzéseként elmondhatjuk, hogy különböző kutatások alapján a leggyakrabban visszatérő tolmácsolási szakmai etikai elvek (1) a titoktartás, (2) professzionalizmus (3) készségek, szaktudás, szakértelem, (4) folyamatos továbbképzés, (5) pártatlanság, (6) tartalmi és nyelvi pontosság. A titoktartással kapcsolatban érdemes megjegyezni, hogy az ugyan az egyik legelső és leszigorúbb szakmai etikai elv a tolmácsolásban, egyes etikai kódexek kivételes esetekben mégis 
megengedök ennek betartásával kapcsolatban. Ilyen esetek lehetnek az öngyilkosság/emberölés szándéka, gyermekek/idősek bántalmazása, vagy a házastársi erőszak (CHIA), vagy amennyiben az amerikai szövetségi illetve állami törvények megkövetelik a bántalmazás, öngyilkossággal való fenyegetőzés jelentését (NADRID), vagy amikor törvény rendelkezik bizonyos információk felfedéséröl (CIOL). A NAJIT szintén megengedi a teljes titoktartási kivételeket a tolmácsok részéről, amennyiben az etikai kódexe elöírja, hogy a tolmács tudomására jutott információt engedély nélkül nem lehet kiadni. Ez annyit jelent, hogy a tolmácsnak bizonyos esetekben engedélyezhetik a teljes titoktartás megszegését.

A professzionalizmussal és viselkedéssel kapcsolatban elmondható, hogy ezekre részletesebben a bírósági vagy egészségügyi tolmácsolási etikai kódexek térnek ki, amelyekben szerepelnek sztenderdizált eljárási illetve viselkedési protokollok. A készség, tudás és szakértelem nagy hangsúlyt kap általában, és konkrétan abban a kontextusban, hogy etikailag elvárható, hogy a tolmács csak olyan megbízásokat fogadjon el, amelyek magas színvonalú elvégzéséhez rendelkezik a megfelelő készségekkel és tudással (nyelvi, háttértudás, valamint kisebb-nagyobb mértékben kulturális). A formális képzettség, képesítés követelménye ehhez közvetlenül kapcsolódik (lásd pl. CHIA, NAD-RID, AUSIT, EULITA, AIIC), mint a tolmácsolási megbízások elvállalásának feltétele és a hivatásos tolmácsolás minőségének garanciája. Érdekes megjegyezni, hogy az AUSIT pl. a képesítés követelményénél megfogalmazza azt a kitételt, hogy bizonyos ritkábban beszélt nyelvek esetében nincs formális képzésre lehetőség. Ez Magyarországon is így van olyan nyelvek esetében, amelyek ritkábban szerepelnek a magyarral egy nyelvkombinációban. Ilyenkor az ELTK BTK Fordító- és Tolmácsképző Tanszéke által szervezett képesítő vizsgán szerezhető meg a tolmácsképesítés. Az AUSIT szerint a szakmai továbbképzés az ilyen esetekben is elengedhetetlen. A megfelelő munkakörülmények (hang- és képminőség, felkészülési lehetőség, konszekutív tolmácsolás esetén a jegyzeteléshez szükséges körülmények, stb.) is azon etikai elvek között szerepelnek, amelyeket a tolmácsoknak be kell tartaniuk, amennyiben ezek nagymértékben befolyásolják a tolmácsolás minőségét.

Érdekes megjegyezni, hogy az AIIC etikai kódexe nem említ két, már-már egyetemesnek számító tolmácsetikai alapelvet. Ezek a pártatlanság és a nyelvi, tartalmi pontosság. A pártatlanság elvének hiánya talán azzal magyarázható, hogy az AIIC etikai kódexe konferenciatolmácsok számára készült, akiknek a munkakörülményei markánsan elkülönülnek a többi tolmácsolási helyzetben jellemző körülményektöl. A konferenciahelyzetben való tolmácsolásra az AIIC sztenderdjeinek megfelelően tolmácskabinban kerül sor, ami azt jelenti, hogy a tolmácsok és az esemény részvevői között kevesebb lehetőség van a közvetlen érintkezésre. A felhasználókkal való kevesebb interakció azt is jelentheti, hogy a tolmácsok ritkábban találják magukat szembe ilyen jellegü dilemmával. Az pedig, hogy az AIIC etikai kódexe nem tér ki a nyelvi és tartalmi pontosságra, úgy értelmezhetö, hogy az AIIC a pontosságot nem etikai, hanem kognitív kérdésnek tekinti. A jól képzett hivatásos tolmácsoktól elvárható a magas színvonalú teljesítmény, amely 
magában foglalja a forrásnyelvi beszéd pontos, teljes és hủ átültetését a célnyelvre. Érdemes megjegyezni, hogy pl. a CHIA, a NAJIT és a EULITA szerint a tolmácsolási hibák beismerése és kijavítása a tolmács etikai kötelessége.

A munkakörülmények mint tolmácsolásetikai kérdés az AIIC, tehát a konferenciatolmácsok esetében kapja a legnagyobb hangsúlyt. Az AIIC etikai kódexe részletesen és kimerítően írja le azokat a paramétereket, amelyek pl. az esemény helyszínén a tolmácskabinból való látási viszonyokra, a hangminőségre, a kényelemre, a munkadokumentumok és a beszédek írásos változatának rendelkezésre bocsátására vonatkoznak. Mindezt az AIIC szerint a megbízónak kell biztosítania. Ez annyiban válik tolmácsetikai kérdéssé, hogy a megbízás elvállalása előtt a tolmácsnak a munkakörülményeket figyelembe véve kell eldöntenie, hogy elvállaljae azt. A munkakörülmények ugyanis egyike azoknak a tényezőknek, amelyek alapvetően meghatározzák a konferenciatolmács teljesítményének minőségét.

\section{Az új technológiák által előidézett tolmácsolásetikai kérdések}

Az új információs és kommunikációs technológiák alapjaiban változtatták meg életmódunkat, azt ahogy dolgozunk, és természetesen a tolmácsolási szakmára is nagy hatást gyakoroltak. A tolmácsok már digitális kabinban dolgoznak, ahol mesterséges intelligencia (MI) alapú terminológiamenedzsment eszközök állnak rendelkezésükre. Ezeknek az eszközöknek a használata még nem terjedt el nagymértékben a tolmácsolási piacon, azonban nagy érdeklődés érezhető irántuk (AIIC UK\&Ireland 2020, Čeňková 2020). A 2020 tavaszáig kialakult egészségügyi válság miatt a tolmácsolás nagy része is otthoni munkavégzéssé vált, ami az online távtolmácsolási platformok (RSI platform) térnyeréséhez vezetett a tolmácsolási piacon, nem csak a magánszférában, hanem a nagy nemzetközi intézményeknél is. Ezek a változások új szükségleteket és igényeket generáltak, a tolmácsok részéröl pedig olyan új tolmácsolási módokat és helyzeteket eredményeztek, amelyek etikai jellegü kérdéseket is felvetnek.

A MI által támogatott, a tolmácsok számára kifejlesztett terminológiamenedzsment eszközök a közelmúltban jelentek meg. A szinkrontolmácsolás közben a terminológiai munka a tolmácsolási esemény alatt is folyamatos, ezért az ilyen rendszereknél arra van szükség, hogy a folyamatok egy része automatizált legyen. Ezek az eszközök neurális hálózatokon alapuló automatikus beszédfelismerést (ASR) használó szoftverek, amelyek a mélytanulás technológiáját alkalmazzák. Ezeket az eszközöket egyfajta „mesterséges kabintársként” (artificial boothmate) lehet felfogni, amelyek a forrásnyelvi beszéd azon lexikai elemeit ajánlják fel a tolmács számára, amelyek problémát jelenthetnek az üzenet kognitív feldolgozása alatt: feliratozzák az előadó szóbeli közlését, vagy kivonatolják a legfontosabb szakkifejezéseket, a tulajdonneveket, a mértékegységeket és a számokat.

Ezekkel az eszközökkel kapcsolatban az információk bizalmas kezelése ad okot etikai jellegü aggodalomra. Az egyik legelterjedtebb ilyen eszköz, az InterpretBank, például a következő elven müködik. Az akusztikai jelet a tolmács meg- 
kapja a fejhallgatóján keresztül, amely ezt követően eljut annak a számítógépnek a hangkártyájára, amelyre a tolmács feltelepítette a szoftvert és amelyet a tolmácsolás során használ. Ezt követően a jel eljut az InterpretBank API-jára (Application Programming Interface), amely a németországi Drezdában található szerveren müködik (Defranq és Fantinuoli 2020). Az adatbiztonság és adatbiztonság szempontjából az adatátvitel megbízhatósága, valamint a tolmácsolási eseményen elhangzottak bizalmas kezelése okozhat etikai jellegü problémát. Mivel igen fiatal és még nem elterjedt technológiáról van szó, érdemes tisztázni, hogy az előadókat milyen módon és mikor kell tájékoztatni arról, hogy az általuk elhangzott beszéd kikerül abból a körből és környezetböl, ahová szánták. Azt is érdemes átgondolni, hogy vajon kell-e ahhoz a beleegyezésüket kérni, hogy a beszédüket távoli szervereken dolgozzák fel. Enélkül ugyanis a tolmácsok szándékuktól eltérően óhatatlanul is megszegik a titoktartási és a tudomásukra jutott információk bizalmas kezelésére vonatkozó etikai követelményt. Ezzel egy időben az előadók jogait, különös tekintettel a szerzői jogokra, is megszeghetik.

Az adatbiztonság és titoktartás kérdését az online távtolmácsolási platformok használatakor is figyelembe kell venni tolmácsolási módtól (konszekutív vagy szinkron) függetlenül, beszélt és jelnyelvi tolmácsolás esetén is. Az online tolmácsolási platformok lehetővé teszik, hogy egy eseményre a részvevők és a tolmácsok a világ bármely részéről bejelentkezzenek, akár úgy is, hogy mindenki más-más helyszínen tartózkodik. Az ilyen platformok használata a 2020 tavaszán kialakult egészségügyi világválság és az otthonról való munkavégzés során hirtelen megugrott. Jóllehet a technológia már rendelkezésre állt egy ideje, használatuk a válság következtében nyert valódi létjogosultságot, amikor a helyszíni eseményeket eltörölték és ezeken a platformokon tartották meg.

Természetesen a jövőt nehéz elöre látni, azonban valószínűsíthető, hogy a covid-19 világjárvány hosszú távú hatása a tolmácsolási piacra az lesz, hogy az online távtolmácsolás velünk marad a válság elmúltával is, akár úgy, hogy a tolmácsok otthonról, akár úgy, hogy egy tolmácsolási központból dolgoznak majd. Az online tolmácsolás volumene valószínű csökkenni fog a járvány végeztével, hiszen feltehetőleg a személyes megbeszélések aránya növekedni fog az összes tolmácsolt eseményen belül. Mindazonáltal az online tolmácsolási platformok a válságból megerösödtek, hiszen a nemzetközi és többnyelvü megbeszélések, konferenciák, találkozók ezeknek az eszközöknek köszönhetően folytatódhattak a világválság alatt.

Az új információkommunikációs eszközök, a mesterséges intelligencián alapuló tolmácsolási terminológiakezelő eszközök igen hasznosnak bizonyulhatnak a tolmácsolási piacon, mind az ügyfelek, mind a tolmácsok számára. Ahhoz nem fér kétség, hogy a tolmács szakmának lépést kell tartania a technológiai fejlődéssel. Mindazonáltal nem szabad megfeledkeznünk az új eszközök által felvetett etikai kérdésekről sem, hiszen a tolmácsokat és ügyfeleiket megilleti az alapvető adatvédelmi biztonság. Annál is inkább, mivel a diszkréció és a titoktartás a tolmács szakma egyik legalapvetőbb etikai követelménye. 


\section{Konklúzió}

A tolmácsolási szakma fordulóponthoz érkezett. Az új technológiák, a mesterséges intelligenciát használó nyelvtechnológiai eszközök megjelenése a tolmácsolási piacon új tolmácsolási helyzeteket és munkakörülményeket eredményezett. Ennek hatását a tolmácsolási piac összes szereplője érzi már, a tolmácsok, a magánpiaci közvetítők, a konferenciatechnikusok, a rendezvényszervezők, a tolmácsolási szolgálatokat müködtető közintézmények, a szakmai szervezetek, valamint a tolmácsképző szakma egyaránt.

A technológiai fejlődés pozitív hatásai közé tartozik, hogy támogathatja a tolmács munkáját, amennyiben pl. a teminológiamenedzsment eszközök csökkentik a tolmácsolás során fellépő kognitív terhelést, az online tolmácsolási platformok pedig lehetővé teszik a nehezen megközelíthető helyeken vagy ritkább nyelvkombinációban elérhető tolmácsolást. Azonban nem szabad elfeledkezni arról sem, hogy mindennek szakmai etikai vonzatai is vannak, a tolmácsolás módjától és fajtájától függetlenül. A legszembetünőbb ezek közül titoktartást, az információk bizalmas kezelését, az adatbiztonságot érintik, amelyek a tolmácsolás során a tolmács-ügyfél kapcsolat alapját képező bizalmi viszonyra lehetnek kihatással.

Egy másik szempont a tolmácsolás minősége, amelyet a munkakörülmények igen nagy mértékben befolyásolnak. Az online platformok lehetővé teszik az otthonról való munkavégzést, amikor is a tolmács partner és technikus nélkül a számítógépe képernyője elött végzi a munkáját, s a tolmácsolt kommunikációs folyamat résztvevőivel igen korlátozott a kapcsolata. Sérül a multimodális (auditív és vizuális) információfeldolgozás, ami a tolmácsolási szakmában minőségi okokból igen nagy jelentőségü. A magas minőségü munkavégzésre való törekvés pedig hangsúlyosan szerepel az alapvető tolmácsolásetikai elvek között.

Az otthonról való munkavégzéssel kapcsolatban egy másik etikai aggodalom is felmerül, nevezetesen a felelősség kérdése a technikai hibák és fennakadások, valamint az információvesztés, az adatok nem biztonságos kezelése esetén: vajon a tolmácsot, az informatikusokat, a megbízót, vagy a rendezvényszervezőt lehet ilyen esetekben felelősségre vonni? Úgy tünik, elérkezett az idő, hogy ezeket az alapvető etikai kérdéseket a szakmai szervezetek keretein belül a szakma is megtárgyalja, és ezek a szakmai etikai kódexekben is helyet kapjanak. Ezenfelül elengedhetetlennek tünik, hogy az új tolmácsolási eszközök fejlesztői már a fejlesztés folyamata során figyelembe vegyék ezeket. Mint ahogy az is, hogy a technológiai fejlődés által támasztott új etikai kihívások iránti érzékenyítés a tolmácsképző programokba is belekerüljön. 


\section{Irodalom}

AIIC UK \& Ireland (2020. december 11.). With a Little Help From My Friends $\mid$ AI for Interpreter Support and Training Artificial Intelligence and the Interpreter webinar series - Part 3.

Angelelli, C. 2003. The Interpersonal Role of the Interpreter in Cross-Cultural Communication. A Survey of Conference, Court, and Medical Interpreters in the US, Canada and Mexico. In: Brunette, L., Bastin, G., Hemlin, I., Clarke, H. (eds) The Critical Link 3. Amsterdam/Philadelphia: John Benjamins Publishing Company. 15-26.

Bancroft, M. 2005. The Interpreter's World Tour: An Environmental Scan of Standards of Practice for Interpreters. Washington.

Bischoff, A., Kurth, E., Henley, A. 2012. Staying in the middle: A qualitative survey of health care interpreters' perception of their work. Interpreting Vol.14. No.1. 1-22.

Bot, H. 2003. The Myth of the Uninvolved Interpreter Interpreting in Mental Health and the Development of Three-Person Psychology. In: Brunette, L., Bastin, G., Hemlin, I., Clarke, H. (eds) The Critical Link 3. Amsterdam/Philadelphia: John Benjamins Publishing Company. 27-36.

Čeňková, I. (2020. december 9-11). Intelligence artificielle : un concept qui soulève beaucoup de questions parmi les étudiants et les interprètes. Elhangzott: CIUTI Conference 2020. ISIT, Párizs, Franciaország.

Defranq, B., Fantinuoli, C. 2020. Automatic speech recognition in the booth. Assessment of system performance, interpreters' performances and interactions in the context of numbers. Target Vol. 33. No. 1 73-102.

Diriker, E. 2004. De-/Re-contextualizing Conference Interpreting. Amsterdam/Philadelphia: John Benjamins Publishing Company.

Edwards, A. B. 1995. The Practice of Court Interpreting. Amsterdam/Philadelphia: John Benjamins Publishing Company.

Fowler, Y., Ng, E., Coulthard, M. 2013. Legal interpreting. In: Millán, C., Bartrina, F. (eds) The Routledge Handbook of Translation Studies. London and New York: Routledge. 402-414.

Gentile, A., Ozolins, U., Vasilakakos, M. 1996. Liaison Interpreting. A Handbook. Melbourne: Melbourne University Press.

Grbič, N. 2015. Profession. In: Pöchhacker, F. (eds) Routledge Encyclopedia of Interpreting Studies. London and New York: Routledge. 321-326.

Hale, S. B. 2004. The Discourse of Court Interpreting: Discourse practice of the Law, the Witness and the Interpreter, Amsterdam/Philadelphia: John Benjamins Publishing Company.

Horváth I. 2013. Bírósági tolmácsolás. Budapest: ELTE Eötvös University Press.

Horváth I. 2015. Bevezetés a tolmácsolás pszichológiájába. Budapest: ELTE Eötvös Kiadó.

Horváth I., Tryuk, M. 2021. Ethics and Codes of ethics in Conference Interpreting. In: Tiselius, E., Alb-Mikasa, M. (eds) Routledge Handbook of Conference Interpreting. London and New York: Routledge. (előkészületben)

Lee, J. 2009. Conflicting views on court interpreting examined through surveys of legal professionals and court interpreters. Interpeting Vol. 11. No. 1. 35-56. 
Kalina, S. 2015. Ethical challenges in different interpreting settings, MonTI, Special Issue Vol. 2. 63-86.

Katan, D., Straniero-Sergio, F. 2001. Look Who's Talking. The Ethics of Entertainment and Talkshow Interpreting. The Translator Vol.7. No. 2. 213-237.

Kermit, P. 2007. Aristotelian ethics and modern professional interpreting. In: Wadensjö, C., Dimitrova, B. E., Nilsson, A.-L. (eds) The Critical Link Vol. 4. 241-249.

Mikkelson, H. 2000. Introduction to Court Interpreting. Manchester, UK, Northampton MA: St. Jerome Publishing.

Mikkelson, H. 2013. Community interpreting. In: Millán, C., Bartrina, F. (eds) The Routledge Handbook of Translation Studies. London and New York: Routledge. 389-401.

Monacelli, C. 2009. Self-preservation in Simultaneous Interpreting. Amsterdam/Philadelphia: John Benjamins Publishing Company.

Monacelli, C., Punzo, R. 2001. Ethics in the Fuzzy Domain of Interpreting. The Translator Vol. 7. No. 2. 265-282.

Phelan, M., Rudvin, M., Skaden, H., Kermit, P. S. 2020. Ethics in Public Service Interpreting, London \& New York: Routledge Taylor \& Francis Group.

Pöchhacker, F., Shlesinger, M. (eds) 2002. The Interpreting Studies Reader. London and New York: Routledge.

Roy, C. 2002 [1993] The Problem with definitions, descriptions, and the role metaphors of interpreters. In: Pöchhacker, F., Shlesinger, M. (eds) The Interpreting Studies Reader. London and New York: Routledge. 344-354.

Setton, R., Prunč, E. 2016. Ethics. In: Pöchhacker, F. (eds) Routledge Encyclopedia of Interpreting Studies. London and New York: Routledge. 144-148.

Schweda Nicholson, N. 1994. Professional Ethics for Court and Community Interpreters. In: Hammond, D. L. (eds) Professional Issues for Translators and Interpreters. American Translators Association Scholarly Monograph Series. Amsterdam/Philadelphia: John Benjamins Publishing Company. 79-97.

Snyder, N. 1994. The Paradox of Professionalism. In: Hammond, D. L. (eds) Professional Issues for Translators and Interpreters. American Translators Association Scholarly Monograph Series. Amsterdam/Philadelphia: John Benjamins Publishing Company. 13-21.

Tate, G., Turner, G. H. 2002. The Code and the Culture. Sign language interpreting - in search of the new breed's ethics. In: Pöchhacker, F., Shlesinger, M. (eds) The Interpreting Studies Reader. London and New York: Routledge. 374-383.

Van Wyke, B. 2013. Translation and ethics. In: Millán, C., Bartrina, F. (eds) The Routledge Handbook of Translation Studies. London and New York: Routledge. 548-560.

Wadensjö, C. 1998. Interpreting as Interaction. London and New York: Longman.

\section{Internetes hivatkozások}

Code of Ethics of Australian Institute of Interpreters and Translators (AUSIT), https:// ausit.org/code-of-ethics/, utolsó megtekintés: 2021. 04. 08. Code of Ethics and Professional Responsibilities of National Association of Judiciary Interpreters and Translators (NAJIT), https://najit.org/wp-content/uploads/2016/09/NAJITCodeofEthicsFINAL.pdf, utolsó megtekintés: 2021. 02. 19. 
Code of Professional Conduct of the Chartered Institute of Linguists (CIOL), https://www. ciol.org.uk/sites/default/files/Code_5.pdf, utolsó megtekintés: 2021. 02. 19.

Code of Professional Conduct of the US Registry of Interpreters for the Deaf (NAD-RID), https://drive.google.com/file/d/0B-_HBAap35D1R1MwYk9hTUpuc3M/view, utolsó megtekintés: 2021. 02. 19.

Code of Professional Ethics of the European Legal Interpreters and Translators Association (EULITA), https://www.eulita.eu/en/code-ethics/, utolsó megtekintés: 2021. 04. 08.

Code of Professional Ethics of the International Association of Conference Interpreters (AIIC), https://aiic.org/document/6299, utolsó megtekintés: 2021. 04. 08.

Standards for Healthcare Interpreters, Ethical Principals, Protocols and Guidance on Roles and Intervention of the California Healthcare Interpreting Association's Standards (CHIA), http://www.chiaonline.org/Resources/Documents/CHIA\%20Standards/standards_chia.pdf, utolsó megtekintés: 2021. 02.19.

Etikai Kódex, Magyar Fordítók és Tolmácsok Egyesülete, https://mfte.hu/hu/mfte/etikaikodex, utolsó megtekintés: 2021. 02. 19. 